\title{
Effects of repeated paleoearthquakes on the Alhama de Murcia Fault (Betic Cordillera, Spain) on the Quaternary evolution of an alluvial fan system
}

José J. Martínez-Díaz $\left({ }^{1}\right)$, Eulalia Masana $\left({ }^{2}\right)$, José L. Hernández-Enrile $\left({ }^{1}\right)$ and Pere Santanach $\left({ }^{2}\right)$

${ }^{1}$ ) Departamento de Geodinámica, Universidad Complutense de Madrid, Spain

${ }^{(2)}$ Departamento de Geologia Dinàmica i Geofísica, Universitat de Barcelona, Spain

\begin{abstract}
In this work we present a study of an alluvial fan system, which is affected by the Quaternary activity of the leftlateral, reverse Alhama de Murcia Fault (Betic Cordillera). Paleoseismic studies in this area yield data that can be compared and correlated with the morphologic and tectono-sedimentary evolution of the alluvial fan. The spatial arrangement of the sedimentary alluvial fan units near the fault zone, shown in trenches, is controlled by the recurrent reverse, left-lateral coseismic events. We analysed the morphology of the drainage network using a 1:5000 scale orthoimage to identify and measure horizontal deflections along the fault. The channel pattern analysis allowed us to estimate the average horizontal slip rate of the SAMF for the last $130 \mathrm{ka}$. This value is $0.21 \mathrm{~mm} / \mathrm{a}$, which is slightly higher than the range of values obtained by trenching analysis for the last $30 \mathrm{ka}$, ( 0.06 to $0.15 \mathrm{~mm} / \mathrm{yr})$. The interpretation of the stratigraphic sequence exposed along the trench walls constrained the occurrence of at least two surface faulting earthquakes during the last 30000 years. The most recent event happened after the El Saltador Creek dissected the alluvial fan. The penultimate event occurred while the alluvial fan was still active.
\end{abstract}

Key words paleoseismicity - slow active faults fan morphology - Alhama de Murcia Fault - Betic Cordillera

\section{Introduction}

In this work, we present a study of the El Saltador alluvial fan, which is situated in the Southeastern Betic Cordillera (fig. 1a-c), and is associated with an active mountain front created by the Lorca-Totana section of the Alhama de Murcia Fault (fig. 2a,b). The distal area of

Mailing address: Dr. José J. Martínez-Díaz, Departamento de Geodinámica, Universidad Complutense de Madrid, Ciudad Universitaria, 28040 Madrid, Spain; e-mail: jmdiaz@geo.ucm.es this fan is affected by a strand of the fault that shows Quaternary activity.

The Southeastern Betic Cordillera is located in the southeast of the Iberian Peninsula close to the area where the African and the Eurasian plates converge. The convergence direction is NNW-SSE with a relative velocity of 4 to $5 \mathrm{~mm} / \mathrm{yr}$ (Argus et al., 1989). Since this low velocity is distributed in a broad area (Meghraoui et al., 1996), the velocity of the active faults in this area is lower than $0.2 \mathrm{~mm} / \mathrm{yr}$ (Martínez-Díaz, 1998). The instrumental seismicity is scattered over the region (Sanz de Galdeano et al., 1995) and has low magnitude (fig. 1a-c). However, several historical earthquakes with magnitude greater than 6.5 occurred in the Central and Southeastern Betic Cordillera (Buforn et al., 1995). 


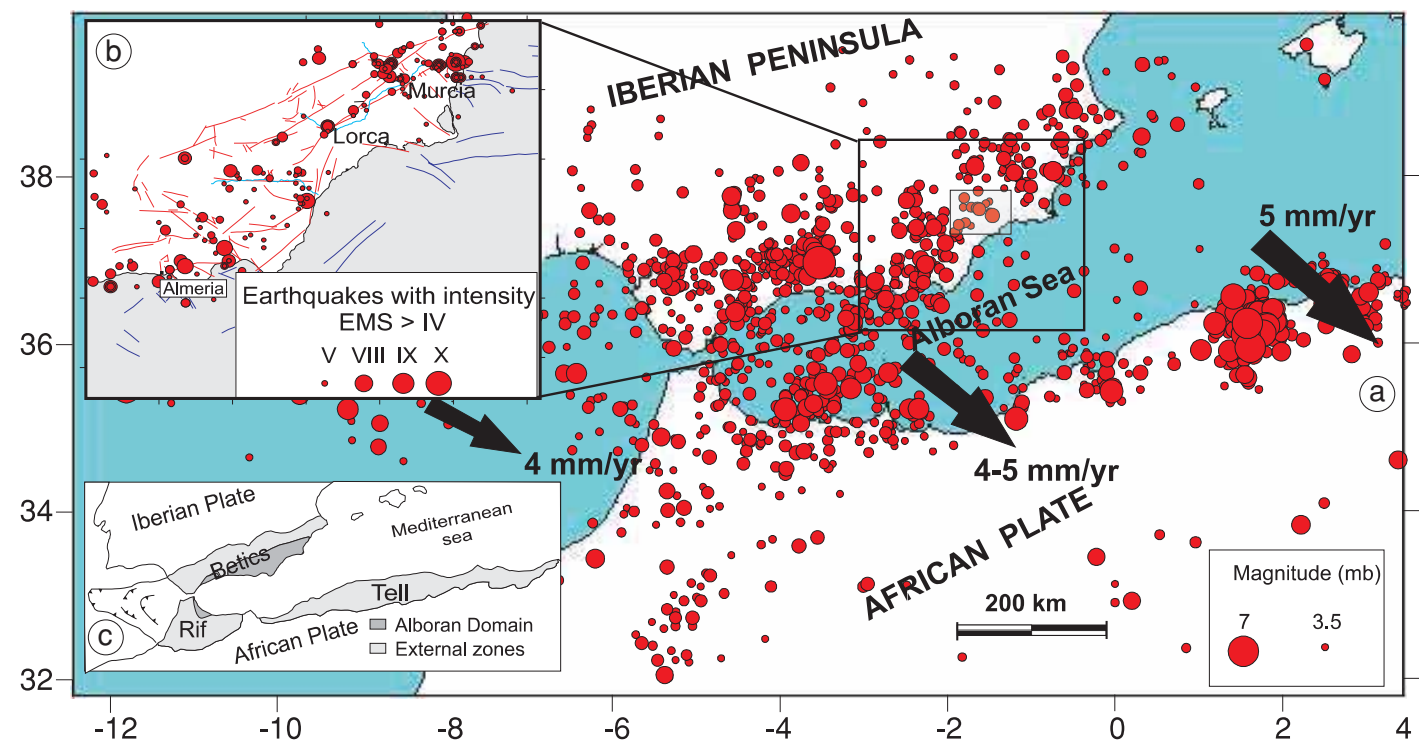

Fig. 1a-c. a) Map showing the location of the study area (square) and the instrumental seismic activity (period 1930-2001) related with the convergence of the Eurasian and African plates. The velocity vectors of plate convergence are taken from Argus et al. (1989). The increase in velocity from west to east is produced by the increasing distance to the eulerian pole of the African plate. b) Seismic activity with intensity > IV occurred in the Eastern Betic Cordillera from 500 A.D. to 2000, projected on a map of the Quaternary faults. Seismic data from the Instituto Geográfico Nacional. c) Regional map showing the regional frame of the study area with the situation of the internal zone (metarmorphic units of the Alboran Domain) of the Betic Cordillera, and the mesozoic and tertiary tectono-sedimentary units of the external zone of the cordillera.

The mountain fronts in the study area have experienced several phases of alluvial fan sedimentation and many of them are controlled by Quaternary active faults. These faults appear to have controlled the history and modality of alluvial fan generation (Harvey, 1990; Silva et al., 1992a). Until now, the relationship between faulting and Quaternary depositional phases of the alluvial fans has been analysed only in terms of long-term tectonic influence (Silva et al., 1992c; Silva, 1994; Martínez-Díaz, 1998). No studies dealing with the effects of recurrent paleoseismic activity on alluvial fan deposits and morphology exist for this area.

Recent paleoseismic studies in this area using trenching data (Hernández-Enrile et al.,
2000; Martínez-Díaz et al., 2001) yield data that can be compared and correlated with the data obtained from our study of the morphologic and tectono-sedimentary evolution of the alluvial fan. To achieve this correlation we first carried out an analysis of the tectono-sedimentary features of the fan using field data from natural outcrops and from two trenches dug on the alluvial fan surface across the fault trace. Then we show a morphotectonic analysis using a digital elevation model built at the 1:5000 scale. Estimates of horizontal movement across strike-slip and oblique-slip faults are typically difficult to obtain from trenching data. We analysed the morphology of the drainage using a 1:5000 scale orthoimage to identify and measure horizontal deflections along 

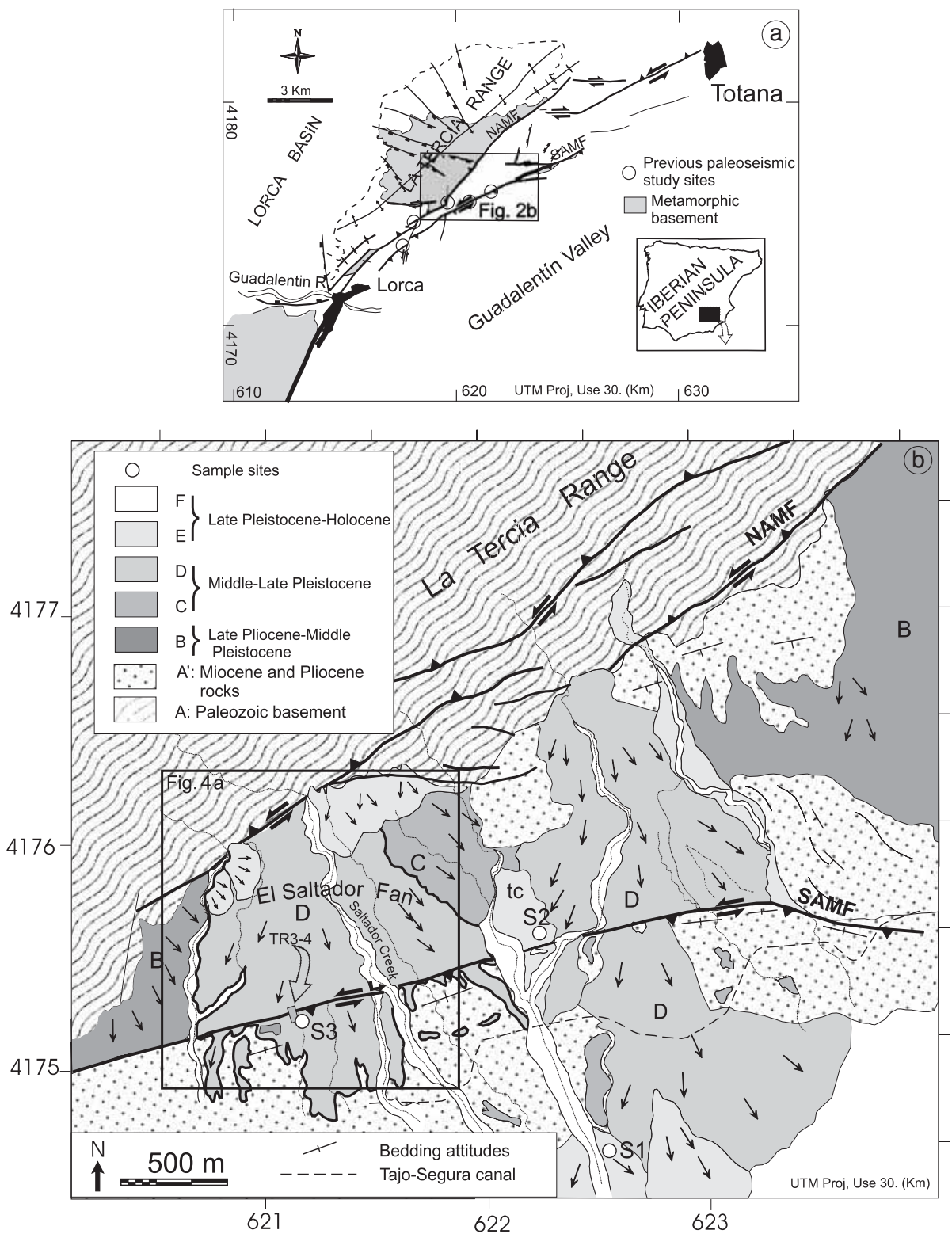

Fig. 2a,b. a) Schematic tectonic map of the Lorca-Totana section of the Alhama de Murcia Fault. This fault is a left-lateral, reverse fault composed of two NE-SW strands: the Northern Alhama de Murcia Fault (NAMF) NW-dipping, high angle reverse fault, and the Southern Alhama de Murcia Fault (SAMF) SE-dipping, high angle left-lateral, oblique-slip fault. b) Map of the Quaternary sediments in the studied area. The largest Middle-Late Pleistocene alluvial fans are related to the El Saltador and Colmenar creeks, and are cut by the SAMF and the NAMF. The small arrows represent the main drainage directions on top of the alluvial fan surface. S1-3 show the sampling sites were 13 samples from the upper layers of the alluvial fans were collected and dated (tables II and III). Tc - fluvial terrace of Colmenar. 
the fault, to estimate horizontal slip rate, and to understand the evolution of the fan after the fluvial incision which caused the alluvial fan surface to become inactive.

The mean recurrence time of large earthquakes with surface expression on slow intraplate active faults situated near plate-tectonic boundaries may range between $10^{4}$ to $10^{5}$ years (Scholz, 1990). The preservation of the geologic and geomorphic evidence of past earthquakes depends on relative rates of the surface processes versus tectonic deformation (Wallace, 1986). For slow fault zones, the rates of geomorphic processes may exceed the tectonic deformation rates and the paleoseis-mic evidence, if preserved, is likely to be only stratigraphic (McCalpin, 1996, p. 17). In many cases, this makes the identification of fault traces difficult. As a general rule larger faults are associated with larger longterm cumulated deformation of the surface, with the pattern of surface coseismic deformation being in relationships with the fault geometry and kinematics. As a consequence, the analysis of the geomorphic elements and/or the sin-tectonic geologic strata can be used to constrain the geometrical parameters and slip type of the tectonic source.

The main subject of this paper is to understand how the tectonic activity influenced the development of geomorphic features and how to use it to correctly interpreting the punctual information coming from trenches, and to do a preliminary estimate of the horizontal displacement of an left-lateral, oblique-slip fault with paleoseismic activity.

\section{Geological setting}

\subsection{Structure of the Lorca-Totana area}

The Southeastern Betic Cordillera is the area with the highest seismic activity in the Iberian Peninsula (fig. 1a-c). There are several Quaternary faults > $50 \mathrm{~km}$-long making this area of particular interest for paleoseismic and seismic hazards studies. The longer faults are NE-SW oblique-slip and strike-slip faults. They are active under a NNW-SSE shortening direction (Montenat et al., 1987). Smaller NW-SE normal faults are also active during the Quaternary. Both sets of faults started its activity in the Middle Miocene and they controlled the geometry and evolution of the basins and ranges during the Pliocene and the Quaternary (Montenat and Ott d'Estevou, 1996). The El Saltador alluvial fan is situated along the southeast front of the La Tercia Range (fig. 2a,b). This mountain front is controlled by the Alhama de Murcia Fault (Bousquet and Montenat, 1974), a NE-SW trending (N $45^{\circ}$ to $65^{\circ} \mathrm{E}$ ) leftlateral, oblique-slip Quaternary fault, up to 80 $\mathrm{km}$ long. The NNW-SSE compressive tectonic regime has caused the fault to move in a left-lateral, reverse fashion which uplifted the $\mathrm{La}$ Tercia Range and triggered the alluvial sedimentation along the front of the range (Armijo, 1977; Silva, 1994; Martínez-Díaz, 1998). Recent paleoseismic studies performed along the Alhama de Murcia Fault (fig. 2a,b) demonstrate the occurrence of at least two oblique-slip paleoearthquakes with magnitude $>6.5$ and with surface rupture during the last 30000 years (Hernández-Enrile et al., 2000; Martínez-Díaz et al., 2001).

The Alhama de Murcia Fault has been divided into four tectonic segments on the basis of differences in orientation, secondary fracture patterns and differences in Quaternary slip (Silva et al., 1992b; Martínez-Díaz and Hernández-Enrile, 1999). The El Saltador alluvial fan is located along the $15 \mathrm{~km}$ long segment situated between the towns of Lorca and Totana (fig. 2a). In this area, the Alhama de Murcia Fault consist of two principal NESW fault strands (fig. 2b). The north-western strand (NAMF) is a left-lateral, oblique-slip fault that dips steeply to the northwest and forms the SE boundary of the La Tercia range. The south-eastern strand (SAMF) is a left-lateral, oblique-slip fault that dips steeply to the southeast, separating in some places Miocene conglomerate, marl and gypsum to the southeast from Quaternary alluvial fan deposits to the northwest. The mountain front was created by the activity of the NAMF, but the SAMF has absorbed most of the shortening in this area since the Messinian, and affects the upper layers of the larger Pleistocene alluvial fans (Martínez-Díaz, 2002). 


\subsection{Quaternary sedimentation in the Lorca-Totana area}

Since the Pleistocene, the climate of the Southeastern Betic Cordillera has been semiarid (Amor and Florschultz, 1964). Under these conditions the sedimentation along the tectonically driven mountain front of the La Tercia range is characterized by the superposition of alluvial fans (Bousquet and Philip, 1976; Silva et al., 1992 a,b; Baena et al., 1993). The development of alluvial fans all over the Southeastern Betics is characterized by a change from dominantly aggradational to dominantly dissectional dynamics. According to differences of calcrete crust development the aggradation phases appear to predate the Würm phase and the dissection phases appear to be Würm and Holocene (Harvey, 1984, 1990). Early phases generated the fan surfaces with development of calcrete crusts, and later phases were dominated by dissection resulting in incision of alluvial channels (Silva, 1994).

In the Lorca-Totana area the Quaternary deposits extend along the southern border of the La Tercia Range. They unconformably overlie the metamorphic rocks of the Paleozoic basement and Late Miocene marine deposits. We recognize four sedimentary units

Table I. Quaternary alluvial units defined in the study area.

\begin{tabular}{|c|c|c|c|c|}
\hline $\begin{array}{c}\text { Units } \\
\text { (label in figs. } \\
\text { 2b and 3) }\end{array}$ & Sediments & $\begin{array}{l}\text { Sedimentary } \\
\text { environment }\end{array}$ & Age & Age criteria \\
\hline $\begin{array}{l}\text { (O) No cartogra- } \\
\text { phic expression }\end{array}$ & $\begin{array}{l}\text { White gravels with } \\
\text { oolitic limestone } \\
\text { clasts proceeding } \\
\text { from the External } \\
\text { Zone of the chain } \\
\text { ( } 30 \mathrm{~km} \text { far to the } \\
\text { north) and grey and } \\
\text { brown silt beds. }\end{array}$ & $\begin{array}{l}\text { Marginal system } \\
\text { deposited during } \\
\text { the transition from } \\
\text { marine sedimenta- } \\
\text { tion to located allu- } \\
\text { vial sedimentation } \\
\text { along the newly } \\
\text { formed tectonic } \\
\text { mountain fronts. }\end{array}$ & $\begin{array}{l}\text { Late Pliocene- } \\
\text { Early Pleistocene }\end{array}$ & $\begin{array}{l}\text { Regional sedimentary } \\
\text { evolution (Silva, 1994) }\end{array}$ \\
\hline B & $\begin{array}{l}\text { Silts, sands, gravels } \\
\text { and conglomerate } \\
\text { with a number of } \\
\text { calcrete levels. maxi- } \\
\text { mum observed thick- } \\
\text { ness is } c a .20 \mathrm{~m}\end{array}$ & $\begin{array}{l}\text { Alluvial fans along } \\
\text { the tectonic moun- } \\
\text { tain fronts }\end{array}$ & $\begin{array}{l}\text { Middle } \\
\text { Pleistocene }\end{array}$ & $\begin{array}{l}\text { Regional sedimentary } \\
\text { evolution (Silva, 1994) }\end{array}$ \\
\hline C, D & $\begin{array}{l}\text { Silts, sands, gravels } \\
\text { and conglomerate } \\
\text { with a number of } \\
\text { well developed cal- } \\
\text { crete levels. }\end{array}$ & $\begin{array}{l}\text { Alluvial fans along } \\
\text { the tectonic moun- } \\
\text { tain fronts. }\end{array}$ & $\begin{array}{l}\text { Middle to Late } \\
\text { Pleistocene }\end{array}$ & $\begin{array}{l}\text { Radiocarbon dating } \\
\text { (see table II) }\end{array}$ \\
\hline $\mathrm{E}, \mathrm{F}$ & $\begin{array}{l}\text { Smaller sized shale, } \\
\text { quartzite and } \\
\text { dolomite clasts com- } \\
\text { ing from the } \\
\text { Alpujárride and } \\
\text { Maláguide metamor- } \\
\text { phic units predomi- } \\
\text { nate in these fans. } \\
\text { No calcrete levels. }\end{array}$ & $\begin{array}{l}\text { Alluvial fans and } \\
\text { fluvial terraces }\end{array}$ & $\begin{array}{l}\text { Late Pleistocene- } \\
\text { Holocene }\end{array}$ & $\begin{array}{l}\text { Regional sedimentary } \\
\text { evolution (Silva, 1994), } \\
\text { radicarbon and thermo- } \\
\text { luminiscense dating } \\
\text { (see tables II and III) }\end{array}$ \\
\hline
\end{tabular}




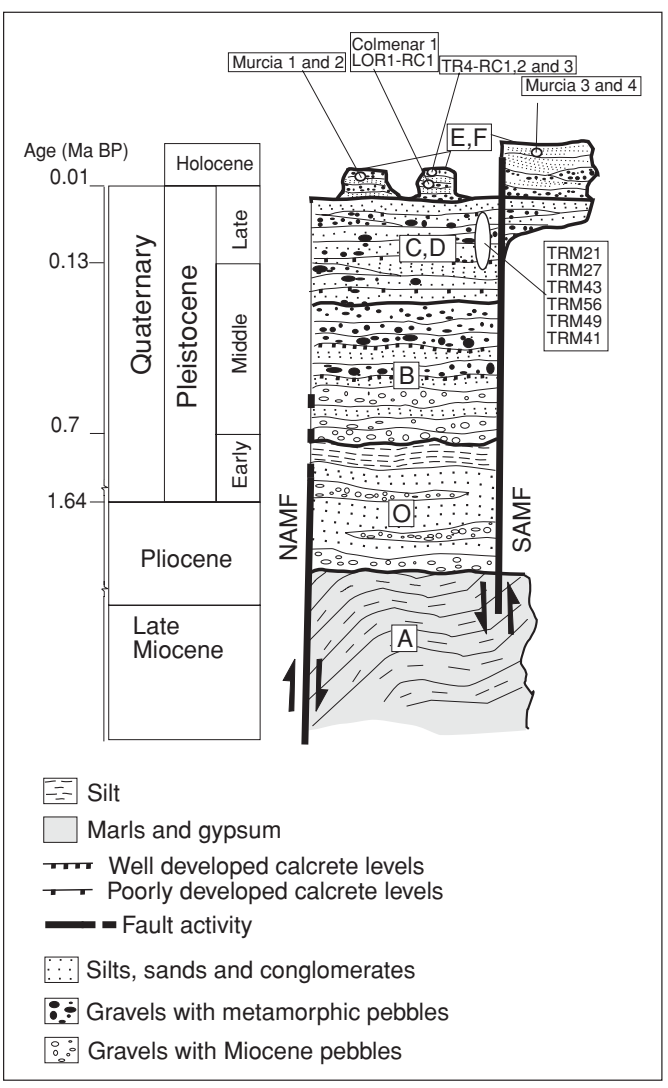

Fig. 3. Stratigraphic column of the Quaternary units differentiated in this work. It is represented the extent of relative outcrop of each unit. The units A and $\mathrm{B}$ are restricted to the downthrown block situated between the two main fault branches of the Alhama de Murcia Fault. The southern strand (SAMF) starts its activity in the Late Miocene and affects Holocene deposits of units E and F. The northern strand (NAMF) was active since Early Miocene and decreased its activity during the Quaternary. All the units are labeled with the same letters in fig. 2b, with the exception of unit $\mathrm{O}$ that is absent on the map. It was only observed on the vertical banks of the creeks. The position of the samples dated with absolute methods is also represented (tables II and III).

defined by their lithology, relative position and deformation style (see table I and fig. 3). The outcrop extent of the Quaternary alluvial units is controlled by the tectonic activity.
The combined activity of the two fault strands has created a NE-SW trending topographic lowland that is filled with the Quaternary sediments (fig. 2b). The outcrops of the PlioceneLower Pleistocene unit $(\mathrm{O}$ in fig. 3) and the Lower to Middle Pleistocene unit (B in figs. $2 \mathrm{~b}$ and 3 ) are restricted to the foot-wall. The upper layers of the Middle to Upper Pleistocene unit (C, D in figs. 2b and 3) are affected by the SAMF but they spill over the fault zone.

We have estimated the ages of these units by correlation with previously dated (using climatic criteria) analogue deposits of this region and by absolute dating. We dated silt samples taken from the uppermost two meters of alluvial fans and terraces. 6 samples using thermoluminiscense and 9 samples using radiocarbon methods (tables II and III). These samples were collected at the points labelled $\mathrm{S} 1-3$ in fig. $2 \mathrm{~b}$ and their ages constraint the time of the deformations described in this work that affect the alluvial fans to the Late Pleistocene and Holocene.

\section{EI Saltador alluvial fan}

\subsection{Sedimentation}

The El Saltador fan is a Middle-Late Pleistocene alluvial fan (Martínez-Díaz, 1998) that occupies an area of $c a .8 \mathrm{~km}^{2}$ (figs. $2 \mathrm{~b}$ and $4 \mathrm{a}, \mathrm{b}$ ). This fan is entrenched by the El Saltador Creek. Along the river banks of this creek is exposed a sedimentary sequence that consists of a facies association of debris flow sediments capped by mudflow horizons. Channels filled with stream sediments are incised into the debris flows and mudflows. Channel deposits are progressively more abundant in the upper part of the sequence. This type of sedimentation is observed in exposures of other fans belonging to the same depositional phase all over the area (Silva et al., 1992a).

The activity of the southern strand of the Alhama de Murcia Fault (SAMF) affects the current fan morphology being expressed by a northfacing scarp, and has also partially controlled its sedimentary evolution. Two trenches were dug across the fault scarp, and we analysed the tec- 
Table II. Absolute ages obtained with radiocarbon method for 9 samples collected at sites S1, S2 and S3 (see fig. 2b). Silty samples are AMS dates and Charcoal and Shell are conventional method dates. Measured $\mathrm{C}^{13} / \mathrm{C}^{12}$ were calculated relative to the PDB-1 international standard and the radiocarbon years before present ages were normalized to $-25 \%$. Dates were done at Beta Analytic.

\begin{tabular}{|c|c|c|c|c|c|c|}
\hline Sample & $\begin{array}{l}\text { Loc. in } \\
\text { fig. } 2 b\end{array}$ & Material & Localisation & $\begin{array}{c}\mathrm{C}^{13} / \mathrm{C}^{12} \\
(\% 0)\end{array}$ & $\begin{array}{l}\text { Conventional } \\
\text { radicarbon age }\end{array}$ & $\begin{array}{l}\text { Calibrated } \\
2 \sigma \text { age }\end{array}$ \\
\hline MURCIA 1 & $\mathrm{~S} 2$ & Silt & $\begin{array}{l}\text { Colmenar terrace } \\
1.5 \mathrm{~m} \text { beneath } \\
\text { the surface }\end{array}$ & -24.8 & $6350 \pm 40 \mathrm{BP}$ & 5335-5240 B.C. \\
\hline MURCIA 2 & $\mathrm{~S} 2$ & Silt & $\begin{array}{l}\text { Colmenar terrace } \\
2.7 \mathrm{~m} \text { beneath } \\
\text { the surface }\end{array}$ & -25.3 & $8220 \pm 50 \mathrm{BP}$ & 7410-7040 B.C. \\
\hline COLMENAR 1 & S2 & Silt & $\begin{array}{l}\text { Colmenar terrace } \\
0.8 \text { m beneath } \\
\text { the surface }\end{array}$ & -21.0 & $2850 \pm 70 \mathrm{BP}$ & 1215-830 B.C. \\
\hline LORC 1 - RC-1 & $\mathrm{S} 2$ & Silt & $\begin{array}{l}\text { Colmenar terrace } \\
1.3 \mathrm{~m} \text { beneath } \\
\text { the surface }\end{array}$ & -22.6 & $3390 \pm 40 \mathrm{BP}$ & 1760-1600 B.C. \\
\hline TR4-RC2 & S3 & Shell & $\begin{array}{c}\text { Unit A, TR-4 } \\
\text { pounding event }\end{array}$ & -7.3 & $1350 \pm 40 \mathrm{BP}$ & 640-720 A.D. \\
\hline TR4-RC3 & $\mathrm{S} 3$ & Charcoal & $\begin{array}{l}\text { Unit A, in TR-4 } \\
\text { pounding event }\end{array}$ & -22.8 & $340 \pm 40 \mathrm{BP}$ & 1450-1650 A.D. \\
\hline TR4-RC8 & S3 & Silt & $\begin{array}{c}\text { Unit B, TR-4 } \\
\text { pounding event }\end{array}$ & -24.2 & $480 \pm 40 \mathrm{BP}$ & 1410-1460 A.D. \\
\hline MURCIA 3 & $\mathrm{~S} 1$ & Silt & $\begin{array}{l}\text { Silty layer } 20 \mathrm{~cm} \text { depth } \\
\text { south of SAMF }\end{array}$ & -25.5 & $820 \pm 40$ & 1170-1280 A.D. \\
\hline MURCIA 4 & $\mathrm{~S} 1$ & Silt & $\begin{array}{l}\text { Silty layer } 45 \mathrm{~cm} \text { depth } \\
\text { south of SAMF }\end{array}$ & -24.0 & $1690 \pm 50$ & 245-450 A.D. \\
\hline
\end{tabular}

Table III. Absolute corrected ages (in years before the present) obtained with thermoluminiscense method for 6 samples collected at site S3 (see fig. 2b). The values of beta, gamma and cosmic dose-rate assessments are shown.

\begin{tabular}{|c|c|c|c|c|c|c|c|c|}
\hline Sample & $\begin{array}{l}\text { Loc. } \\
\text { fig. } \\
2 b\end{array}$ & $\begin{array}{l}\text { Unit/ } \\
\text { trench }\end{array}$ & $\begin{array}{l}\text { BetaNRD } \\
\quad(\mathrm{Gy})\end{array}$ & $\begin{array}{c}\text { Beta + external } \\
\text { dose-rate } \\
(\mathrm{Gy} / \mathrm{ka})\end{array}$ & $\begin{array}{c}\text { Beta } \\
\text { dose-rate } \\
\text { (Gy/ka) }\end{array}$ & $\begin{array}{c}\text { Gamma } \\
\text { dose-rate } \\
(\mathrm{Gy} / \mathrm{ka})\end{array}$ & $\begin{array}{l}\text { Cosmic } \\
\text { dose-rate } \\
(\mathrm{Gy} / \mathrm{ka})\end{array}$ & $\begin{array}{c}\text { Corrected TL } \\
\text { age } \\
\text { (Ka) BP }\end{array}$ \\
\hline TRM 21 & S3 & I/TR3 & $81.4 \pm 6.6$ & $2.659 \pm 0.204$ & $1.685 \pm 0.191$ & $0.829 \pm 0.071$ & $0.145 \pm 0.011$ & $23.8 \pm 3.1$ \\
\hline TRM 27 & $\mathrm{~S} 3$ & D/TR3 & $40.1 \pm 3.2$ & $1.885 \pm 0.128$ & $0.982 \pm 0.112$ & $0.709 \pm 0.061$ & $0.194 \pm 0.013$ & $17.2 \pm 2.1$ \\
\hline TRM 43 & S3 & D/TR3 & $42.2 \pm 3.9$ & $2.069 \pm 0.145$ & $1.134 \pm 0.129$ & $0.747 \pm 0.066$ & $0.188 \pm 0.015$ & $17.2 \pm 2.3$ \\
\hline TRM 56 & $\mathrm{~S} 3$ & I/TR3 & $102.5 \pm 5.4$ & $2.841 \pm 0.228$ & $1.952 \pm 0.217$ & $0.766 \pm 0.066$ & $0.123 \pm 0.012$ & $25.4 \pm 3.1$ \\
\hline TRM 49 & $\mathrm{~S} 3$ & E/TR3 & $95.1 \pm 7.3$ & $2.951 \pm 0.227$ & $1.938 \pm 0.215$ & $0.855 \pm 0.072$ & $0.159 \pm 0.012$ & $22.2 \pm 3.2$ \\
\hline TRM 41 & S3 & F/TR3 & $42.3 \pm 3.2$ & $2.326 \pm 0.173$ & $1.388 \pm 0.158$ & $0.795 \pm 0.071$ & $0.143 \pm 0.013$ & $14.5 \pm 1.7$ \\
\hline
\end{tabular}



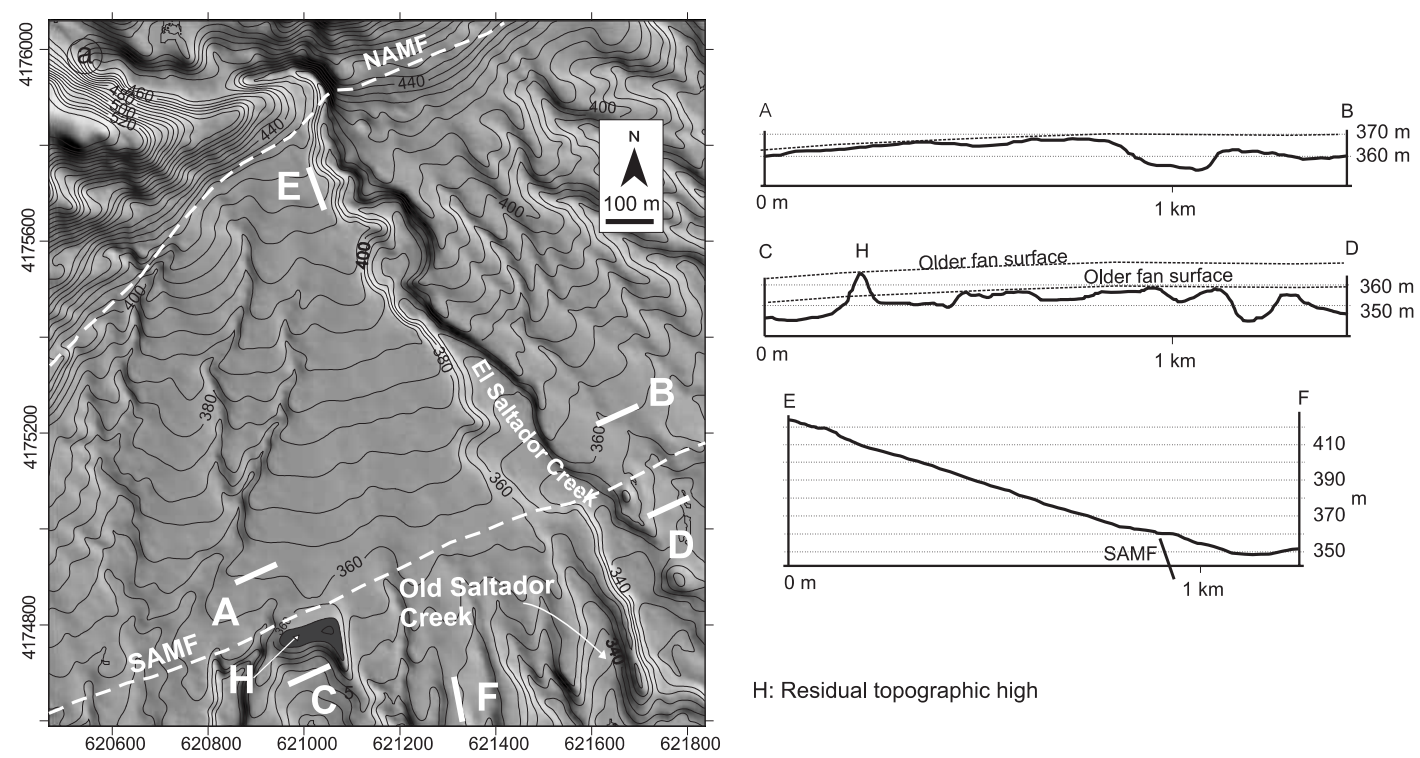

H: Residual topographic high

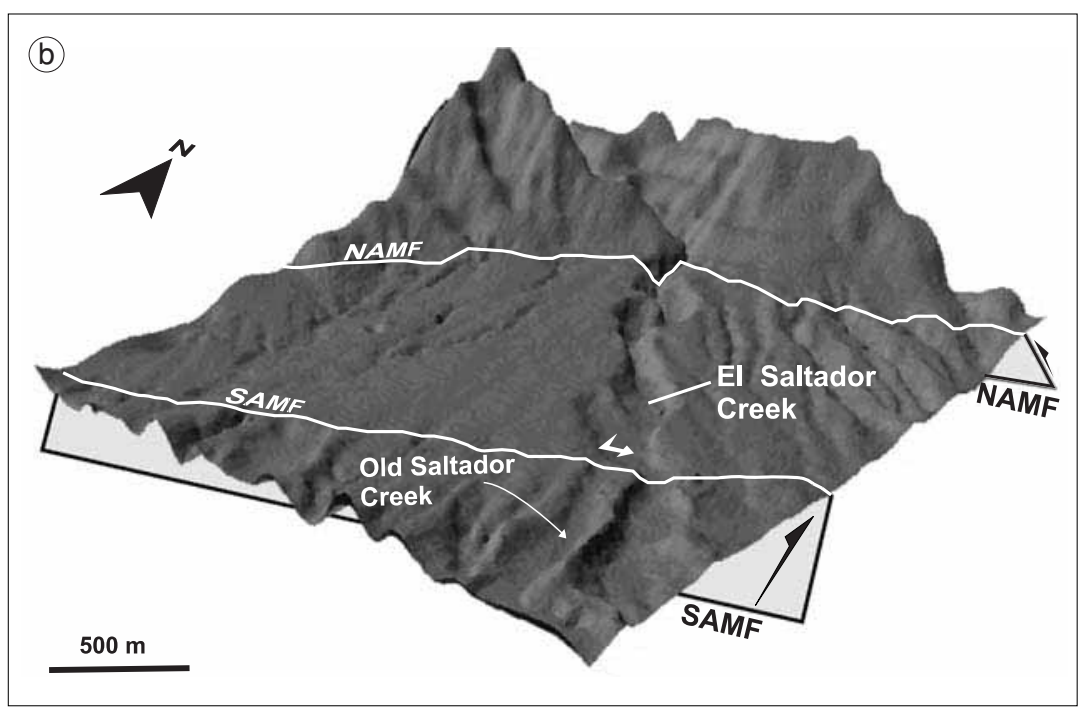

Fig. 4a,b. a) Shaded relief map processed from cartographic data at the 1:5000 scale showing the El Saltador alluvial fan together with the fault traces of the Northern and Southern Alhama de Murcia Fault (NAMF and SAMF). To the right the longitudinal (E-F) and transversal (A-B and C-D) topographic profiles of the fan show different degree of dissection of the fan surface in the foot-wall and hanging-wall of the SAMF. H represents a relict of an old fan surface uplifted in the hanging-wall of the SAMF (upper dashed line in profile C-D). b) Oblique view of the fan surface from the southeast showing the morphology of the fan surface in relationship with the geometry of the two fault strands, and the capture (arrow) experienced by the El Saltador Creek in the fault zone due to headward erosion triggered in the hanging wall by the uplift. 
tono-sedimentary record exposed on the walls to study the sedimentary dynamics of the fan in the vicinity of the SAMF (fig. 5a,b). Trench TR4 was dug in a stream channel while trench TR3 is located $20 \mathrm{~m}$ toward the east on a higher part of the fan surface (fig. 6a). Both trenches expose the uppermost three meters of the fan, deposited prior to the incision of the main channel of El Saltador Creek. This incision caused sedimentation to shift farther downstream, initiating the formation of several small Holocene fans situated $2 \mathrm{~km}$ to the southeast and left the El Saltador fan surface abandoned (fig. 2b).

The trenches also allowed us to study the dynamics of local sedimentation on the fan surface after the end of the fan activity. On the walls of the trenches we observed that the sedimentation of the youngest fan beds was active at the same time with the activity of the SAMF which raised the southern block during paleoseismic events and dammed the river courses, triggering the deposition of finegrained units.

\subsection{Trench $T R 3$}

We divided the alluvial deposits exposed in trench TR3 (fig. 5a) into 9 units using two criteria: i) abrupt lithological changes revealing a change in the sedimentary regime, and/or ii) the

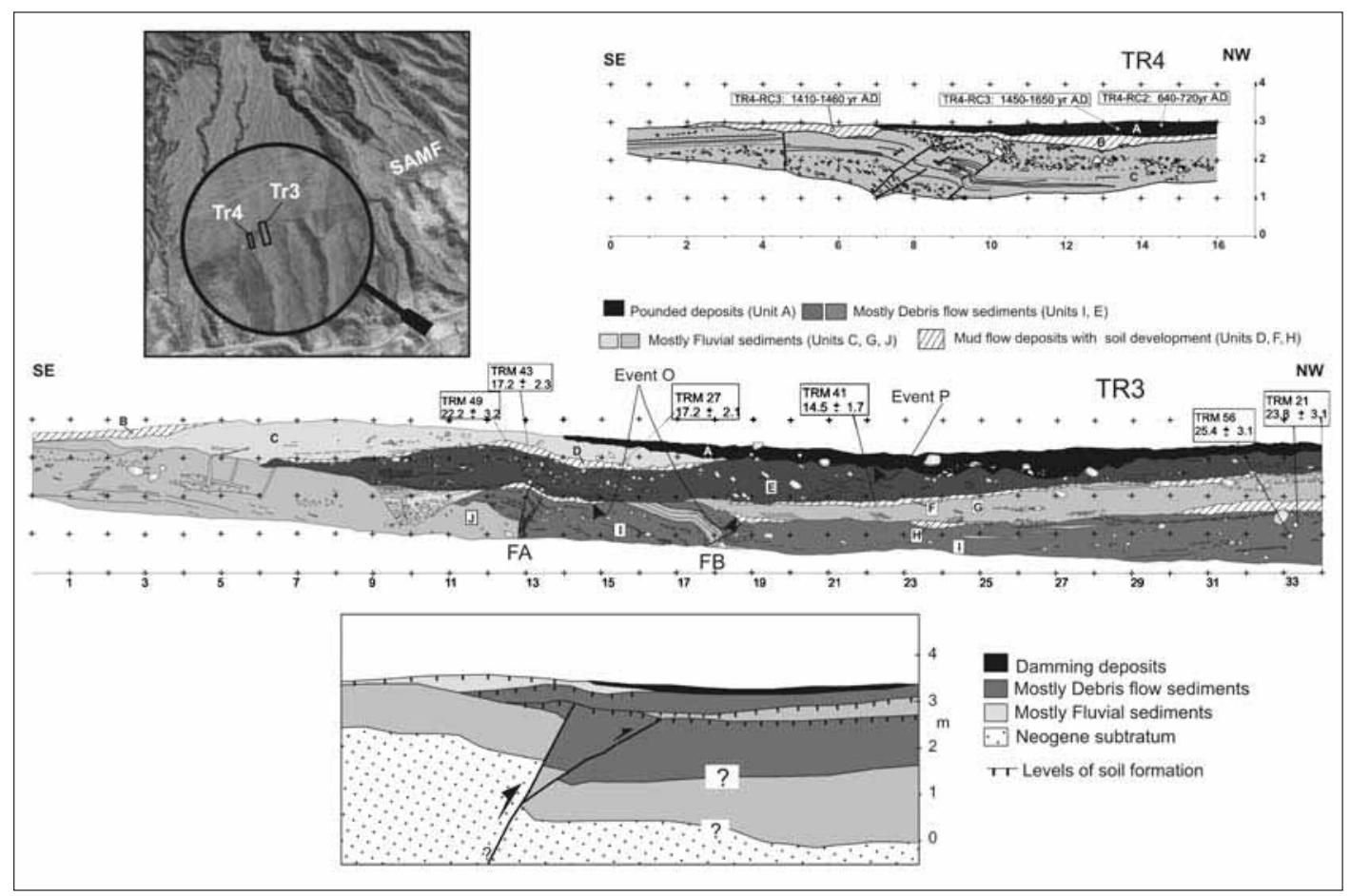

Fig. 5a,b. a) Aerial photograph showing the location of the two trenches dug across the SAMF. The logs of the trenches are interpreted. We differentiated 9 sedimentary units. The units D, E, F, G, H, I and J are clearly affected by the movements of two strands of the SAMF (FA and FB). A is a pounded sedimentary unit that probably was deposited after the coseismic surface bending above the fault FA. At least two events $(\mathrm{O}$ and $\mathrm{P})$ are recognized. Absolute ages obtained from thermoluminiscence and radiocarbon methods are labeled in the logs of the trenches (see tables II and III). b) Represents a tectono-sedimentary interpretation of the trenches, with 5 tectono-sedimentary units created by the paleoseismic activity of the SAMF. 

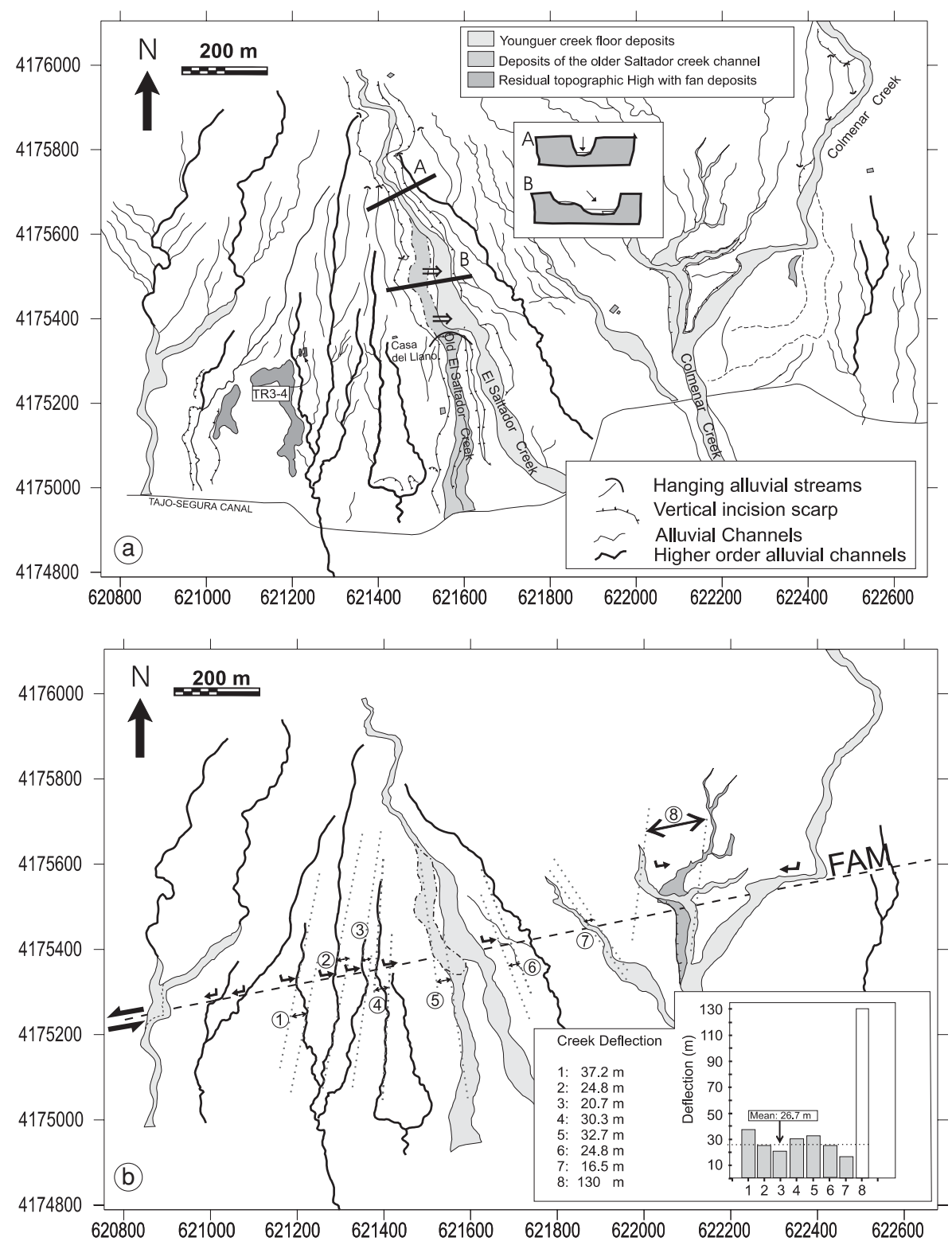

Fig. 6a,b. Geomorphic map of the alluvial network on the El Saltador fan mapped at the 1:5000 scale. a) Complete drainage network along with main morphological features. Darkest grey colour shows the relict topographic high in the hanging wall of the SAMF (see fig. 4a,b). Intermediate grey colour shows the old El Saltador Creek channel before the capture triggered by the headward erosion in the hanging wall. Topographic sections A and B show the asymmetric entrenching of the creek near the fault driven by the capture. Light grey colour represents modern channels. b) The higher order channels are represented together with the fault trace. We measured the systematic left-lateral deflections of the channels crossing the SAMF. The histogram shows the component parallel to the fault of the deflections. Only the grey bars were used to calculate the mean value of deflection. 
existence of angular unconformities indicating the occurrence of surface coseismic deformation. The uppermost three meters of the fan consist of debris-flow deposits alternating with sheet flow deposits. The debris flows consist of matrix-supported gravels with a coarse, grey, sandy matrix. Angular pebbles are typically $2 \mathrm{~cm}$ in size with some up to $40 \mathrm{~cm}$, and are composed of phyllite, diabase, dolomite and quartzite. Gravels are typically capped by mud flow deposits up to several $\mathrm{cm}$ thick. The sheet flow deposits consist of well sorted, loose, clast-supported gravels with coarse sandy matrix. Criteria to determine the debris-flow nature of the deposits include the presence of boulders, matrix-supported structure, poorly sorted textures, absence of stratification, and lack of rounding and sorting of clasts (Sharp and Nobles, 1953; Bull, 1977). On top of the debris flow deposits and in some sheet flow deposits there are mud flow horizons that present incipient calcic soils, generally orange or yellow in colour, with signs of root porosity, suggesting periods of non-deposition. The uppermost unit exposed in the trench (unit $\mathrm{A}$ ) is a package of upward-thinning dark-brown silts. It contains charcoal and gastropod shells and local matrix-supported gravel. We interpret this deposit as being generated by temporary damming produced by the bending of the surface linked to the paleoseismic activity of the fault (fig. 5b). The present, active soil is developed on top of this unit.

\subsection{Trench TR4}

Trench TR4, a 2 m-deep excavation within a channel exposed two types of deposits (fig. 5a). The lower part of the trench exposed a fluvial unit of loose, clast-supported gravels with angular pebbles, commonly imbricated, and containing internal lamination. A brownorange soil has formed on the top this unit. This soil is covered by dark brown, thinning upward, clast-supported gravels that grade into matrix-supported gravels and finally to silts. This uppermost deposit is similar to the upper unit A of trench TR3 and we interpret it as representing the local and temporary pound- ing of the river feeding the fan, due to fault motion.

In summary, the El Saltador fan was built by the accumulation of three types of deposits during the latest aggradational phases: stratified fluvial sand and gravel, debris-flow deposits with gravel and silts, and mud flow deposits. Upon a number of mud flows we observe paleosoils and incipient calcretes with different degrees of development. In the channel (trench TR4) we observe a predominance of fluvial deposits, and neither debris flow deposits nor paleosols are present in contrast to what we observed in trench TR3 at the same topographic level. However, the pounded unit in both trenches indicates that after alluvial fan deposition ceased, the sedimentary record is homogeneous in both of the trenches.

\subsection{Influence of oblique slip movement on the morphology of the El Saltador fan}

The surface of the El Saltador fan has been modified by agricultural activity since the 1950 's. However, the analysis of aerial photographs taken in $1956(1: 33000)$ and the orthoimage at 1:5000 scale allows us to observe its morphology in detail. Furthermore, we have constructed a digital elevation model at a scale of 1:5000 from topographic data at the same scale that enables us to observe, with a $1 \mathrm{~m}$ resolution, the relief on the fan surface from different point of view (fig. 4a). The fan is currently undergoing active headward erosion and El Saltador Creek is entrenched up to $20 \mathrm{~m}$. Figure 6a,b shows the paleo-drainage pattern active during the last aggradational phases as interpreted from the air photos. The channels have large and consistent width/height ratios. They resemble the alluvial fan channels acting alternatively as debris and fluvial channels described by Beaty (1990) in active fan areas with similar climate and lithology.

The El Saltador fan is cut by the SAMF, which trends $\mathrm{N} 55^{\circ}-60^{\circ} \mathrm{E}$ (fig. 2b). It is a south-dipping left-lateral, reverse fault south side up. The digital elevation model (fig. 4a) shows the surface expression of the fault and 
its control of the drainage pattern and river behaviour. Channels are highly entrenched on the southern block due to vertical incision on the hanging wall. A topographical longitudinal profile along the fan surface (fig. 4a profile E-F) shows a change in slope close to the fantoe that is interpreted as due to repeated fault movements. Transverse topographic profiles, parallel to the fault and carried out on both sides of the fault, show different degrees of erosion in the footwall (profile A-B) and in the hanging wall (profile $\mathrm{C}-\mathrm{D}$ ). In the hanging wall, fluvial gravels are preserved on the top of a small topographic culmination ( $\mathrm{H}$ in fig. $4 \mathrm{a}$ ), $10 \mathrm{~m}$ above the current fan surface. We interpret this topographic high as a relict of an old fan surface raised by the fault activity. In addition, headward erosion in the hanging wall induced the channel shift of the El Saltador Creek due to a process of capture when it was flowing $10 \mathrm{~m}$ higher than the present creek bed (see arrow in fig. 4b).

The drainage network on the fan surface (fig. 6a) shows some channels slightly deflected, possibly by left-lateral movement of the
SAMF. The tectonic origin of these deflections is supported by Martínez-Díaz (2000) that in a regional study identifies that more than $70 \%$ of the alluvial channels crossing the SAMF show a left-lateral deflection. The number of data with high quality is inadequate to do a statistical analysis of the relation between the frequency of stream deflection, and the fault displacement for the Lorca-Totana section of the fault. However, we consider that they are good enough in the study area to analyse the fault movement affecting the El Saltador fan. The mean value of the deflections measured on this alluvial fan is $26.7 \mathrm{~m}$ (fig. 6b). The entrenchment of some of the streams along the fault zone causes deflections that is much more large (number 8 of fig. 6b) and it were not considered in the calculation. In a few cases the deflection is right-lateral. These right-lateral deflections were not diverted by the fault activity, but rather followed the gouge (weaker) zone of the fault and/or they were forced by the original low angle between the channel and the fault, similar to those described along other active strike-slip faults (Huang, 1993). The left-

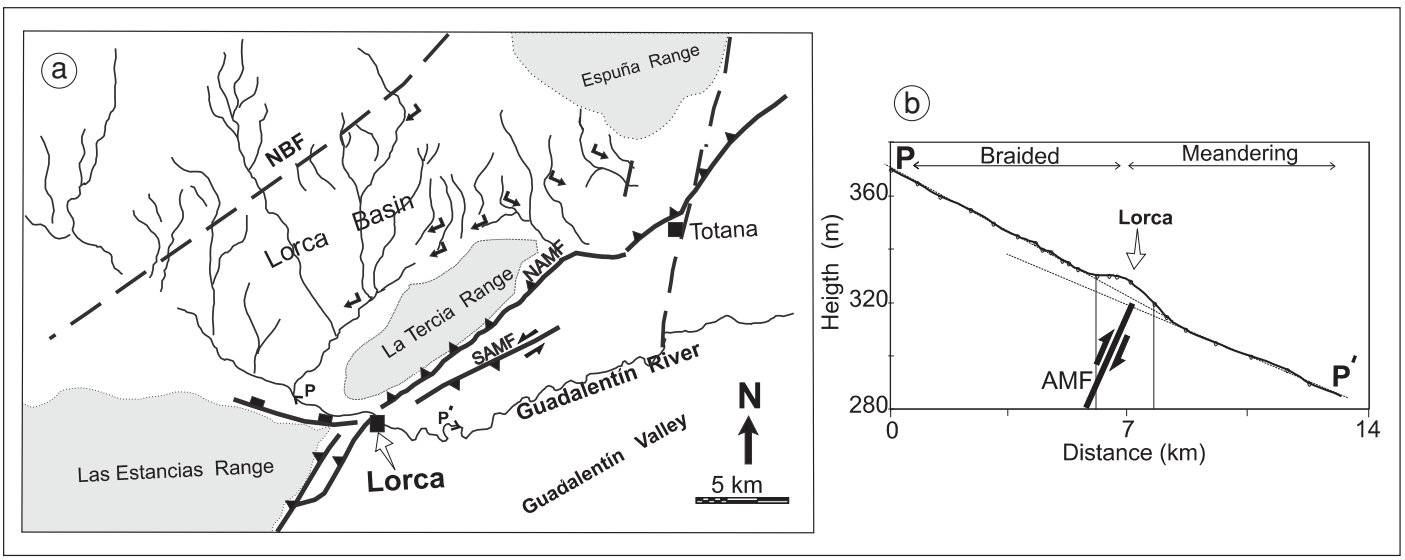

Fig. 7a,b. a) Drainage network of the Guadalentín River in the vicinity of the Lorca-Totana section of the Alhama de Murcia Fault Zone. The white arrow shows the point along the Guadalentín River where a change in the fluvial pattern (from braided to meandering) is observed. This change coincides with a change of slope in the longitudinal profile of the river (b), and take place crossing Ahama de Murcia Fault (AMF). This profile was drawn using 1:10000 topographic maps. NBF - Northbetic Fault. Black arrows show the deflection of a Pliocene fluvial network due to the tectonic uplift of La Tercia Range. 
lateral deflection is clearest on the better-preserved channels designated 1-7 on fig. $6 \mathrm{~b}$ and it is also visible along the old El Saltador channel (shaded zone in fig. 6a). The capture of the old El Saltador Creek by the present El Saltador Creek (arrow in fig. 4b) also produced an apparent deflection in the present creek larger than the deflection of the older creek. The asymmetry of the transverse profile of the El Saltador Creek valley close to the fault (profile B of fig. 6a) agree with an asymmetrical headward erosion of the valley triggered by the capture. Only the deflection of the Old Saltador Creek is considered as a tectonic feature.

The influence of the Holocene activity of the Alhama de Murcia Fault in the Quaternary alluvial network is also observed at a more regional scale. The uplift of the La Tercia Range driven by the reverse movement of the NAMF, produced the deflection of the old PlioceneEarly Pleistocene fluvial network in the Lorca Basin (fig. 7a,b). In addition, an abrupt change in slope and a morphologic anomaly in the longitudinal profile of the Guadalentín River occurs where the river crosses the Alhama de Murcia Fault in the vicinity of Lorca (fig. 7b). This change coincides with a shift of the river pattern from a braided pattern in the hanging wall of the Alhama de Murcia Fault to a meandering pattern in the footwall. This very localised change of fluvial pattern indicates very recent relative vertical movements inducing longitudinal changes of the stream gradient (Schumm and Khan, 1972; Bullard and Lettis, 1993).

\subsection{Influence of the fault activity on the El Saltador fan sedimentation}

Drag associated with the reverse movement of the NAMF results in a southward tilting of the proximal deposits of the El Saltador fan. Since the youngest fan deposits are not in contact with this fault, it is difficult to deduce the age of its most recent earthquake activity. However, Holocene alluvial terraces close to the fan apex are undeformed crossing the fault trace. The strong incision of the fans during the Late Pleistocene and Holocene together with the deposition of the
Holocene fans far from the range front can be attributed to a reduction of the range uplift rate, possibly related to a decrease of the activity of the NAMF from the late Pleistocene (as suggested in the geomorphologic study of Silva (1994)), that was coeval with the paleoseismic activity of the southern strand (Martínez-Díaz et al., 2001). During the Quaternary, this fault absorbed most of the NNW-SSE shortening produced by the present stress field. This redistribution of slip produced a decrease of the slip rate of the NAMF and a decrease of the Uplift rate of La Tercia Range that facilitated the entrenchment of the El Saltador Creek in the sediments of the alluvial fan. The upward reduction of the depositional energy observed in the stratigraphy of the $\mathrm{El}$ Saltador fan showed by the fining upward sequence agrees with this process.

The morphology and the sedimentary distribution of the youngest deposits of the medium and distal areas of the El Saltador fan are conditioned by the recurrent paleoseismic activity of the SAMF. This control is observed on the wall of the trenches dug across the fault zone (fig. 5a). Silva et al., (1992a) suggested that the raised southeastern block acted as a shutter ridge, which has been a barrier for sedimentation. However, the stratigraphy observed in the trenches and along the banks of the El Saltador Creek indicates that during deposition of the last $10 \mathrm{~m}$ of the alluvial fan deposits in the downthrown block, the deposits spilled over the southern fault. The structure observed in trench TR3 suggests at least two paleoseismic events due to the movement of the SAMF (faults FA and FB in fig. 5a). The fault FB cut the layers of units $J$ and I. The fault FA bend the units $\mathrm{E}$ and $\mathrm{F}$ and produced pebble rotations in the gravels of unit F. No clear evidence of deformation is observed in units $\mathrm{C}$ and $\mathrm{D}$, however, the natural slope of the alluvial fan surface is modified above the fault FA. This suggests a coseismic bending of the surface. The penultimate event occurred after the deposition of unit I and before unit $\mathrm{F}$ with a vertical displacement (adding the amplitude of the fold to the fault slip) of more than $3 \mathrm{~m}$. Due to this event, units $\mathrm{G}, \mathrm{H}$ and part of I were eroded from the hanging wall. The last event occurred after the deposition of unit $\mathrm{C}$ and before the deposition of unit $\mathrm{A}$, and produced about $1 \mathrm{~m}$ of vertical displacement ex- 


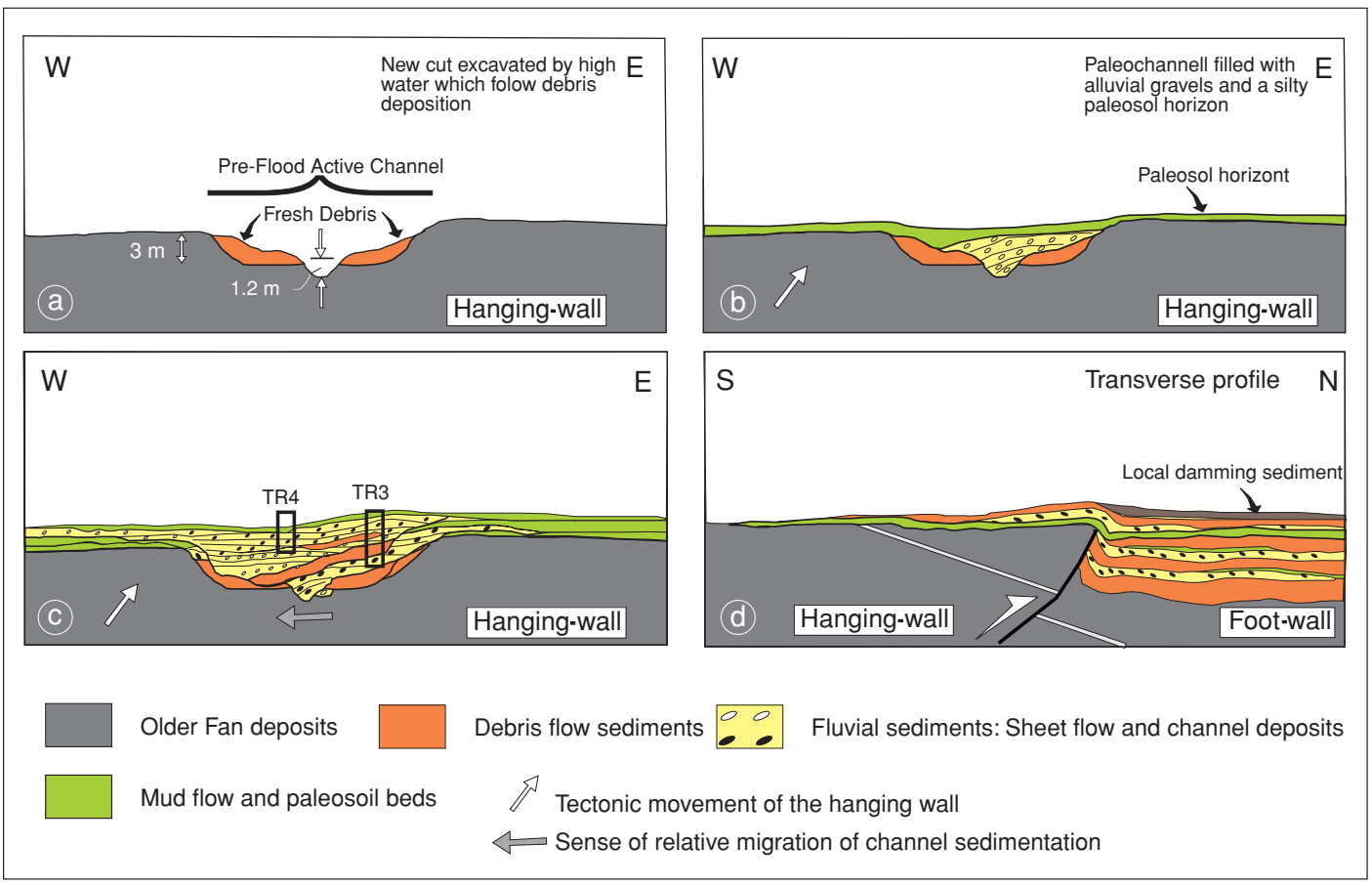

Fig. 8a-d. Model showing sedimentary development of an active debris-fluvial channel in an oblique-slip fault zone. The channel dimensions and the morphology of debris sedimentation are taken from the description of Beaty $(1963,1990)$ for the upper Milner Creek fan. The activity of the fault controls the drainage pattern and behaviour (erosional/depositional in areas undergoing tectonic uplift/subsidence). The ideal sections A, B and C are drawn parallel to the fault (in the hanging-wall) and show that the left-lateral and reverse movement on the fault zone causes the channel to produce vertical and lateral incision. Section D is transverse to the fault and show the sedimentation of pounded deposits of unit A due to the obstruction of the drainage.

pressed as the bending of the topographic surface and the local obstruction of the drainage. The damming caused by this obstruction resulted in the deposition of unit A.

Trench TR3 shows an onlap on the buried fault scarp due to the infilling of the depression located at its foot-wall (fig. 5a). Younger layers cover the fault zone. During the erosion of the hanging wall the fan debris and fluvial channels incised into the raised surface. If we extrapolate these observations of the trenches to the difference in thickness of the fan deposits, seen in a section from the hanging-wall to the foot-wall along the El Saltador Creek exposures (to the southeast of the fault only $2 \mathrm{~m}$ of alluvial de- posits are preserved, while to the northwest the fan thickness exceeds $10 \mathrm{~m}$ ), we infer that the tectonically driven process of uplift, erosion of the hanging wall, and sedimentation on the fault zone has been recurrent during the history of the fan. Bearing in mind that the average recurrence period of paleoseismic events of this fault strand is over 10000 years (Masana et al., 2003), the interseismic periods are long enough to develop complete erosion-sedimentation cycles.

Below the unit A trenches TR 3 and TR4 show different facies associations at the same topographic level. Trench TR4, dug along a channel, shows fluvial deposits and trench TR3 shows 
debris flow, mud flow and fluvial deposits typically capped by paleosols. Figure 8a-d shows the geometry of the sedimentation observed in a typical debris channel. The active channel may alternately play as a debris channel and as a fluvial channel. We consider that the channel cut the block that was uplifted by the fault. The interaction between the recurrent fault activity, which produced uplift in the fault zone, and the sedimentation of the channel may produce substantial differences in the sedimentary record at two closely spaced points. The vertical movement in the fault zone causes the channel to produce vertical incision. The left-lateral offset may induce the erosion to be concentrated on the western bank of the channel, causing sedimentation to migrate laterally. The facies observed in trench TR4 represent the record of the last fluvial sedimentation in the channel before the entrenchment of the El Saltador Creek. The facies association in trench TR3 represents the sedimentation of fluvial channel deposits alternating with the debris-flow and mud flow deposits. We could expect these alternating facies to occur in the areas of debris channel sedimentation abandoned by the westward migration of the channel, as we see here, due to the left-lateral movement of the fault (fig. 8c).

When the fan was entrenched by the deep incision of the current El Saltador Creek, the channel activity on the fan surface ceased. Since then, the channels on the fan surface were characterized by low water discharge as they were no longer connected with the range. The last coseismic reactivation of the fault induced obstruction of these small channels, and consequently, local damming and sedimentation (fig. 8d).

\subsection{Long and short term slip rates}

The paleoseismic studies carried out in the El Saltador fan have demonstrated the occurrence of at least two surface faulting events during the last 35000 years (Martínez-Díaz et al., 2001). Quaternary striations on the fault plane, observed in the trenches and in natural outcrops, present a pitch ranging from $32^{\circ}$ to $60^{\circ}$. These pitch angles confirm the reverse movement with left-lateral component. However, no markers have been identified in the trenches to quantify the horizontal slip rate of the fault. We use the horizontal deflection of the channels on the alluvial fan of $27 \mathrm{~m}$, as deduced above, to estimate the horizontal slip rate of the SAMF. The El Saltador fan formed at the end of the first Quaternary depositional phase of Silva (1994), during the Middle Pleistocene on the basis of climatic criteria. If the channels formed close to the Middle-Upper Pleistocene boundary (130000 years BP), the horizontal slip rate is ca. $0.21 \mathrm{~mm} / \mathrm{yr}$.

The short-term horizontal slip rate during the last 30000 years can be calculated using the pitch of the striations observed on the fault plane and the vertical slip rate (0.10-0.20 $\mathrm{mm} / \mathrm{yr}$ ) deduced from the trenches excavated on the El Saltador fan (Masana et al., 2003). It ranges from $0.15 \mathrm{~mm} / \mathrm{yr}$ for a pitch of $32^{\circ}$ to $0.06 \mathrm{~mm} / \mathrm{yr}$ for a pitch of $60^{\circ}$. The comparison between long- and short-term horizontal slip rates of the SAMF shows values of similar magnitude, even if a little smaller for that of the younger interval (0.06 to $0.15 \mathrm{~mm} / \mathrm{yr}$ ) with respect to the values averaged over the whole Upper Pleistocene-Holocene $(0.21 \mathrm{~mm} / \mathrm{yr})$. This rate is similar to the long-term slip rate estimations of (Martínez-Díaz, 1998) using fault displacements measured in Upper Miocene and Pliocene rocks in the Lorca-Totana segment of the Alhama de Murcia Fault.

This is the first preliminary estimate of Quaternary horizontal slip rate in the Alhama de Murcia Fault. Since the morphology of the study area was highly modified by the agricultural activity, the slip rates are derived from poorly constrained data, and more absolute ages are also necessary to diminish the uncertainty of the results. The stream deflections utilized in this study were measured in topographic maps of adequate scale for a good accuracy. However, more alluvial fans must be analysed in detail to obtain more data and to apply a statistical analysis to the complete Alhama de Murcia Fault.

\section{Conclusions}

We studied the stratigraphy, sedimentology and morphology of a sequence of Quaternary 
alluvial fans in relationship with the paleoseismic activity of the left-lateral, reverse Alhama de Murcia Fault, with the aim of interpreting the tectonic control on the fan dynamics and the fault evolution.

Our results regarding fan dynamics can be summarized as follows:

i) During the last $30 \mathrm{ka}$, the El Saltador fan was built by a succession of stratified sands and gravels, debris-flow with gravels and silts, and thin horizons of mud flow deposits. The geometry of the sedimentation was controlled by the dynamics of debris channels and sheet flows.

ii) The spatial arrangement of the sedimentary units near the fault zone, shown in trenches TR3 and TR4, is partly controlled by the recurrent reverse, left-lateral coseismic events that affected the dynamics of sedimentation in the active fan channels. The recurrent uplift of the hanging wall produced vertical incision of the stream channels and headward erosion that caused most of the fan deposits to be stripped away from the hanging wall. The recurrent eastward movement of the hanging wall produced a relative westward migration of the fluvial sedimentation in the channel.

iii) The entrenchment of El Saltador Creek, triggered a gradual decrease of the geomorphic activity on the fan surface. The last coseismic reactivation of the SAMF induced obstruction of the small fluvial channels on the fan surface, and consequently, local pounding and sedimentation.

Our results regarding fault evolution can be summarized as follows:

i) The channel pattern analysis allowed us to estimate the average horizontal slip rate of the SAMF for the last $130 \mathrm{ka}$. This value is 0.21 $\mathrm{mm} / \mathrm{yr}$, which is slightly higher than the range of values obtained by trenching analysis for the last $30 \mathrm{ka}$ ( 0.06 to $0.15 \mathrm{~mm} / \mathrm{yr})$. This preliminary horizontal quaternary slip rate is the first estimate in the Alhama de Murcia Fault.

ii) The interpretation of the stratigraphic sequence exposed along the trench walls constrained the occurrence of at least two surface faulting earthquakes during the last 30000 years. The penultimate event occurred while the alluvial fan was still active. The most recent event happened after the El Saltador Creek dissected the alluvial fan.

\section{Aknowledgements}

Paleoseismic data presented in this study were obtained within the projects: «Active tectonic analysis of the Murcia region and their application to seismic hazard assessment» AMB97-0523, FAUST project (ENV4-CT970528) and SAFE project (EVG1-CT-2000-23). We thank Carol Prentice and an anonymous reviewer for the constructive comments that helped to improve the manuscript.

\section{REFERENCES}

AMOR, J. M. and F. Florschultz (1964): Results of the preliminary palynological investigation of samples from a $50 \mathrm{~m}$ boring in Southern Spain, Bol. R. Soc. Esp. Hist. Nat. Secc. Geol., 62, 251-255.

Argus, D.F., R.G. Gordon, C. Demets and S. Stein (1989): Closure of the Africa-Eurasia-North America plate motion circuit and tectonics of the Gloria Fault, J. Geophys. Res., 94, 5585-5602.

ARmiJo, R. (1977): La zona des failles Lorca-Totana (Cordillères Bétiques, Espagne). Etude tectonique et neotectonique, M.Sc. Thesis, Paris VII, pp. 229.

BaEnA, J., L.M. Barranco, C. Zazo, J.L. Goy, P.G. Silva, L. Somoza, T. Bardají, A. Estevez, C. Sanz De Galdeano and T. Rodriguez (1993): Mapa Neotectónico, Sismotectónico y de Actividad de Fallas de la Región de Murcia 1:200000 y 1:100000, edited by Instituto Geológico y Medioambiental de España (ITGE-CARM, Madrid).

BEATY, C.B. (1963): Origin of alluvial fans, white mountains, California and Nevada, Assoc. Am. Geographers Annals, 53, 516-535

BeAty, C.B. (1990): Anatomy of a White Mountains Debris-Flow. The making of an alluvial fan, in Alluvial Fans. A Field Approach, edited by A.H. RACHOCKI and M. Church (Willey and Sons, New York), 69-89.

Bousquet, J.C. and C. Montenat (1974): Presence de décrochements NE-SW plio-quaternaires dans les Cordillères Bétiques Orientales (Espagne). Extension et signification général, C.R. Acad. Sci. Paris, 278, 2617-2620.

Bousquet, J.C. and H. PhILlIP (1976): Observations microtectoniques sur la compresion nord-sud Quaternaire des Cordillères Betiques Orientales (Espagne Méridional-Arc de Gibraltar), Bull. Soc. Géol. France, 18, 711-724.

BuLL, W. (1977): Recognition of alluvial-fan deposits in the stratigraphic record, in Recognition of Ancien Sedimentary Environments, edited by W.K. HAMBLIN and J.K. Rigby, Soc. Econ. Paleontol. Mineral., Spec. Publ., 16, 63-83.

Bullard, T.F. and W.R. LetTIS (1993): Quaternary fold deformation associated with blind thrustfaulting, Los Angeles Basin, California, J. Geophys. Res., 98 (B5), 8349-8369. 
Buforn, E., C. Sanz De Galdeano and A. Udías (1995). Seismotectonics of the Ibero-Maghrebian region, Tectonophysics, 248, 247-261.

HaRveY, A.M. (1984): Aggradation and dissection sequences on Spanish alluvial fans: influence on morphological development, Catena, 11, 289-304.

HARVEY, A.M. (1990): Factors influencing Quaternary alluvial fan development in Southern Spain, in Alluvial Fans. A Field Approach, edited by A.H. RACHOCKI and M. CHurch (Willey and Sons, New York), 147-269.

HERNÁNDEZ-ENRILE, J.L., J.J.MARTínEZ-DíAZ, E. MASANA and P. SANTANACH (2000): Resultados preliminares del estudio paleosísmico mediante trincheras de la falla de Alhama de Murcia (Cordillera Bética), Geotemas, 1-4, 335-339.

HuAnG, W. (1993): Morphology patterns of stream channels on active Yishi Fault, Southern Shandong Province, Eastern China: implications for repeated great earthquakes in the Holocene, Tectonophysics, 219, 283-304.

MARTínEZ-DíAZ, J.J. (1998): Neotectónica y tectónica activa del sector centrooccidental de Murcia y Sur de Almería, Cordillera Bética (España), Ph. D. Thesis, Universidad Complutense de Madrid, pp. 466.

MARTíNEZ-DíAZ, J.J. (2000): Indicios geomorfológicos indicativos de tectónica activa en el sector LorcaTotana de la Falla de Alhama de Murcia, Boletín Geológico y Minero, 111 (1), 67-76.

MARTíNEZ-DíAZ, J.J. (2002): Stress field variety related to fault interaction in a reverse oblique-slip fault: the Alhama de Murcia Fault, Betic Cordillera, Spain, Tectonophysics, 356, 291-305.

MARTÍNEZ-DÍAZ, J.J. and J.L. HERnÁNDEZ-ENRILE (1999): Segmentación tectónica de la Falla de Alhama de Murcia y actividad paleosísmica asociada. Contribución a la determinación de la peligrosidad sísmica en la región de Murcia, in Proceedings of Primer Congreso Nacional de Ingeniería Sísmica, Madrid, vol. 1, pp. 75-87.

MartínEZ-Díaz, J.J., E. Masana, J.L. HeRnÁndeZ-EnRILE and P. SANTANACH (2001): Evidence for co-seismic events of recurrent prehistoric deformation along the Alhama de Murcia Fault, Southeastern Spain, Acta Geol. Hisp., 36 (3/4), 315-327.

Masana, E., J.J. Martínez-Díaz, J.L. Hernández-EnRile and P. SANTANACH (2003): The Alhama de Murcia Fault (SE Spain), a seismogenic fault in a diffuse plate boundary. Seismotectonic implications in the Ibero-Magrebian region, J. Geophys. Res., doi: 2002JB002359

McCAlPIN, J.P. (1996): Paleoseismicity (Academic Press, San Diego), pp. 350.
Meghraoui, M., J.L. Morel, J. Andrieux and M. Dahmani (1996): Tectónique plio-quaternaire de la chaîne tello-rifaine et de la mer d'Alboran. Une zone complexe de convergence continent-continent, Bull. Soc. Géol. France, 167 (1), 141-157.

Montenat, C. and P. Ott D'estevou (1996): Late Neogene basins evolving in the Eastern Betic transcurrent fault zone: an illustrated review, in Tertiary Basins of Spain, edited by P.F. FRIEND and C. DABRIO (Cambridge University Press), pp. 400.

Montenat, C., P. Otт D’estevou and P. Masse (1987): Tectonic-sedimentary characters of the Betic Neogene Basins evolving in a crustal transcurrent shear zone (SE Spain), Bull. Cent. Rech. Explo. Prod. Elf Aquitaine, 11 (1), 1-22.

Sanz De Galdeano, C., C. López Casado, J. Delgado and M.A. PEINADO (1995): Shallow seismicity and active faults in the Betic Cordillera. A preliminary approach to sources associated with specific faults, Tectonophysics, 248, 293-302.

Schumm, S.A. and H.R. KHAN (1972): Experimental study of channel patterns, Geol. Soc. Am. Bull., 83, 1755-1770.

SHARP, R.P. and L.H. Nobles (1953): Mudflow of 1941 at Wrightwood, Southern California, Geol. Soc. Am. Bull., 64, 547-560.

Scholz, C. (1990). The Mechanics of Earthquakes and Faulting (Cambridge University Press) pp. 439.

Silva, P. (1994): Evolución geodinámica de la Depresión del Guadalentín desde el Mioceno Superior hasta la actualidad: Neotectónica y Geomorfología, Ph.D. Thesis, Universidad Complutense de Madrid, pp. 642.

Silva, P., J.L. Goy and C. ZAZo (1992a): Discordancias progresivas y expresión geomorfológica de los abanicos aluviales cuaternarios de la depresión tectónica del Guadalentín, Geogaceta, 11, 67-70.

Silva, P., J.L. GoY and C. ZAZO (1992b): Características estructurales y geométricas de la falla de desgarre de Lorca-Alhama, Geogaceta, 12, 7-10.

Silva, P., J.L. Goy, C. Zazo, T. BardaJí, L. Somoza, C.J. DABRIO and J. LARIO (1992c): Evaluación geomorfológica de la actividad tectónica cuaternaria a lo largo de frontes montañosos de falla en el SE de España, in Proceedings of III Congreso Geológico de España y VII Congreso Latinoamericano de Geología, Salamanca, vol. 2, 96-100.

WALLACE, R.E. (1986): Overview and recommendations, in Studies in Geophysics. Active Tectonics (National Academy Press, Washington D.C.), pp. 266. 
